\title{
Revolutionary Justice in Brecht, Conrad, and Blake
}

\author{
Christopher Tomlins
}

\begin{abstract}
Historians have approached the scholarly genre of "law and literature" as a means to mine works of literature for images, descriptions, and representations of law and legal evenes in historical (or historical-analogical) contexts. The questions asked are framed by history and treat literature as source material. Suppose we instead make literature our frame and history our subject. What can literature as form tell historians about "history" as we currently practice it? How might an inspection of literature as a practice change the practice of legal historians? Here I consider the possibilities through an examination of time and justice, and paricularly the time of justice, in three literary works: Bertolt Brecht's Threepenny Novel, Joseph Conrad's Heart of Darkness, and William Blake's poem "London" from Songs of Experience. My principal interlocutor in this exercise is the Marxist literary theorist and historical materialist Walter Benjamin. The conjunction is informative, for Benjamin was deeply engaged in the exposition of concepts of justice. My purpose is to show that literature as practice lends itself wo the strategy of explanation that Benjamin termed "constellation" in ways that are suggestive of how legal historians in turn might employ constellation in approaching questions of time and justice.
\end{abstract}

Keywords: Benjamin, Brecht, Conrad, Blake, time, justice

If the image of justice is here rendered back to us, most often with a shock of recognition, at some rare moments, moments miraculous but not necessarily dismissible, it might also come back to us with a difference, a difference that is both less and more than the dream of objective adequation which justice is: less out of forbearance, and more out of hope. -Wai Chee Dimock, Residues of Justice (1996)

Redemption depends on the tiny fissure in the continuous catastrophe.

-Walter Benjamin, Central Park (c. 1938-39)

Law \& Literature, Vol. 21, Issue 2, Pp. 185-213. ISSN 1535-685x, electronic ISSN 1541-2601. C) 2009 by The Cardozo School of Law of Yeshiva Cniversity. All rights reserved. Please direct all requests for permissisn tos photocopy or reproduce article content through the University of California Press's Rights and Permissions website, at http://wWw.ucpressjournals.com/reprintinfo.asp. DOI: 10.1525 /lal.2009.21.2.185 
Even as they disagree on crucial questions of theory and perspective, scholars active in the genre of "law and literature" are at one in treating the conjunction of these "major human enterprises" as of considerable significance to the study of law. Employing James Boyd White's description of both law and literature as "cultural practices preoccupied with discourse and the shaping of shared meaning through language," for example, Lawrence Douglas grants literature a vital critical role vis-à-vis law. Literature can "explore law's exclusions." It can instruct law in its limits, challenge law "to extend its discursive possibilities." Demonstrably, it has done so.' Richard Weisberg takes White's observation a long step in a different direction. Pointing to the analogous forms of law and literature, to the close relationship between "law's manner of recreating and discussing reality" and "what storytellers themselves are in the business of doing," Weisberg represents literature ("stories and poems") not only as a vital source of knowledge about law, and of critical insight into law, but also as itself a source of law that is "richer and certainly more accessible than those others in legal philosophy that have dominated jurisprudence

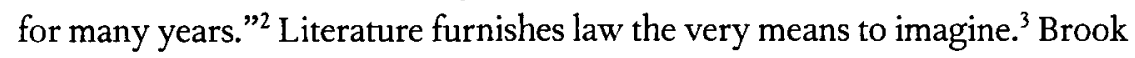
Thomas, on the other hand, has warned against any facile "merger" of law and literature. Using Althusserian language, each is "relatively autonomous," both of context and of the other. "Although both are ultimately related to the period's modes of production and reproduction of social structures, each develops according to a logic of its own." ${ }^{4}$ In their relatively uncoupled structural relationship, however, Thomas (like Douglas) identifies a crucial critical potential in literature vis-à-vis law. "Literature's distance from the direct mode of governance accounts for its capacity to contest a period's dominant legal ideology ... even literature that does not directly engage legal issues can occupy a potential space in which it is informed by a different set of ideological assumptions from those that inform law." Law is a social text rhetorically legitimized to respond "to its historical situation" by addressing conflicts, maintaining order. Whether imaginatively or reflectively, literature (another social text) can hack into that historical situation and dispute it, redefine it, criticize it, offer distinct solutions to conflicts or distinct means to maintain order. ${ }^{5}$

The varied positions taken by leading law and literature scholars on the relationship pertaining between their intersecting subjects have been in many cases deeply informed by extensive historical study. ${ }^{6}$ None of these scholars, however, would identify herself or himself as a historian per se. What 
of those scholars who do so identify? In the hands of historians of law, it is noticeable that literature has been confined to a somewhat more restricted sphere of application. Legal historians mine works of literature in search of images, descriptions, and representations of law and legal events in historical or historical-analogical contexts. The works that excite most interest are those explicitly inflected by law: Eumenides, Bartleby the Scrivener, White Jacket, Billy Budd, Bleak House, The Trial, To Kill a Mockingbird, and so forth. ${ }^{7}$ The questions asked of them treat literature as a locale at which an intersection of culture and law occurs that the historian can access as evidence for use in writing the history of law, or (more expansively) that she or he can treat as in itself an appropriate subject for the history of law: How, in this source, is law or legality represented? How is law enacted? What is law's context? What meaning does this author ascribe to law in this place and time? How do meanings change over time? The questions asked and the answers sought are framed by history's default conventions: time is linear and sequential; past and present are discontinuous; facticity and imagination are distinct; the recovery of meaning is appropriately mediated by the scholar's reflective expertise. ${ }^{8}$ Literature then comes to us wrapped in the method of history.

If we reverse this order of things and make history (particularly legal history) and how we do it the subject for inquiry, we find ourselves on a terrain of debate more closely resembling that occupied by law and literature scholars. What range of possibility exists in the relationship between literature and legal history? What can literature as a form tell historians about "history" as we currently practice it? How might an inspection of literature, not as source or subject but as medium, change the practice of legal historians?

In this essay I consider some possibilities through an examination of how time and justice, and in particular the time of justice, are presented in three literary works. ${ }^{9}$ To a degree, I am borrowing here from two recently published essays in which I have examined the same works, although not with my current purposes in mind. ${ }^{10}$ The three are Threepenny Novel, by Bertolt Brecht; Heart of Darkness, by Joseph Conrad; and the poem "London" from Songs of Innocence and Experience by William Blake."

My principal interlocutor in this exercise is the literary critic and philosopher of history, Walter Benjamin (1892-1940). Indeed, this essay is one fragment in a long slow process of trying to tease out of Benjamin's remarkable and extensive corpus of writing what $I$ think of as his jurisprudence of revolution. ${ }^{12}$ In my view, one can detect in Benjamin a historical and materialist 
jurisprudence that is quite unlike anything we generally include in the category "Marxist theories of law"--the pioneering "capital logic" theorizing of Evgeny Pashukanis, for example, or the later efforts of Althusserian structuralists like Nikos Poulantzas. ${ }^{13}$ Here I experiment with just one element of that exercise in "teasing out": how literature as medium reciprocates the historical materialist strategy that Benjamin calls "constellation," and whether it does so in ways that are at all suggestive of how legal historians in turn might employ that strategy in approaching questions of time and justice.

As I see it, Benjamin developed the concept of constellation, which he also earlier called convolution, in the course of a multifaceted intellectual encounter with Leibniz. ${ }^{14}$ In his translator's foreword to Gilles Deleuze's famous disquisition upon Leibniz, The Fold, Tom Conley calls Leibniz "the first great philosopher of the pleat, of curves and twisting surfaces." 15 Convolution expresses time precisely in this fashion: folded, coiled, twisted; time not straight and sequential, endless extension, but sinuous, wound back on itself. Time, that is, expressed in the way that life itself is lived and recalled. ${ }^{16}$ Benjamin gives voice to the idea of convolution in his I929 essay on Marcel Proust, ${ }^{17}$ whose massive memoir, $\dot{A}$ la Recherche du Temps Perdu, ${ }^{18}$ is famously launched from a fold of pastry - a "petite madeleine" 19 - that is simultaneously a fold of time. Of that fold, Proust writes

When from a long-distant past nothing subsists, after the people are dead, after the things are broken and scattered, still, alone, more fragile, but with more vitality, more unsubstantial, more persistent, more faithful, the smell and taste of things remain poised a long time, like souls, ready to remind us, waiting and hoping for their moment, amid the ruins of all the rest; and bear unfaltering, in the tiny and almost impalpable drop of their essence, the vast structure of recollection. ${ }^{20}$

In Proust, as in Benjamin, the concept of history expresses the past in the present, not locked behind a historical positivist's cæsura as a subject isolated for scientific observation and conscious reflection, or as Gordon Wood rould have it "reconstruction," "ll but "waiting and hoping," immanent in the narration of an actualizing recollection. ${ }^{22}$ Or as Benjamin puts it in his climactic Theses on the Philosophy of History, "to articulate the past historically does not mean to recognize it 'the way it really was.' It means to seize hold of a memory as it flashes up at a moment of danger," at "the instant when it can be recognized." $2+$ 
Constellation expresses this "flashing up" of the past in the present and its recognition, and makes of it a means to penetrate and countermand historicist causality. ${ }^{25}$ It is central to Benjamin's jurisprudence of revolution, as these three extracts from the Theses illustrate:

Thesis $1_{4}$ : History is the subject of a structure whose site is not homogenous empty time, but time filled by the presence of the now.

Thesis A: No fact that is a cause is for that very reason historical. It becomes historical posthumously, as it were, through events that may be separated from it by thousands of years. A historian who takes this as his point of departure stops telling the sequence of events like the beads of a rosary. Instead he grasps the constellation which his own era has formed with a definite earlier one.

Thesis 15: The awareness that they are about to make the continuum of history explode is characteristic of the revolutionary classes at the moment of their action.

So understood, the present moment ceases to be merely an allotted moment of transition to the next moment in a continuum, and so on ad infinitum, but always potentially a moment for itself, of time out of joint; as Benjamin puts it, "a Messianic cessation of happening, or put differently, a revolutionary chance in the fight for the oppressed past." ${ }^{26}$

Interruption-cessation - is central to Benjamin's critique of the conventions of historical practice. "A historical materialist cannot do without the notion of a present that is not a transition, but in which time stands still and has come to a stop. ${ }^{27}$ It is also the central concept in his jurisprudence of revolution. His well-known meditation upon Angelus Novus, for example, represents "the angel of history" contemplating not "a chain of events" but "one single catastrophe which keeps piling wreckage upon wreckage and hurls it in front of his feet." The angel "would like to stay, awaken the dead, and make whole what has been smashed" but he cannot, for he is caught "in a storm ... blowing from Paradise that ... propels him into the future to which his back is turned, while the pile of debris before him grows skyward." ${ }^{28}$ The storm, observes Benjamin, is what we call progress. Its cessation - awakening the dead; making whole what has been smashed - is revolution's justice. How can the storm be interrupted and the angel remain?

For the beginnings of the answer one must turn back to Benjamin's "Critique of Violence" (192I). ${ }^{29}$ "Critique of Violence" was in crucial aspects a meditation upon George Sorel's exposition of revolutionary syndicalism, 
Reflections on Violence. ${ }^{30}$ In Reflections, Sorel argued that the means to interruption was the revolutionary violence of the general strike, the final uprising of the proletariat for itself and for no other. ${ }^{31}$ As a Marxist and a revolutionary, Benjamin's own conception of revolutionary justice (and of historical materialism) would embrace the always potentially recurrent appearance of a revolutionary proletariat in action. ${ }^{32}$ Still, for him the effects for men of their own revolutionary violence were not clear cut. ${ }^{33}$ Like Sorel, "Benjamin wants to conceive of a finality, a justice of ends, no longer tied to the possibility of law." 34 But all species of violence (save only one) were implicated in the making and preserving of the storm of progress and law that was to be interrupted. Law's foundation lay in the mythical violence visited by the gods upon humanity, which is to say that the positing of law is in its fundamental principle "a power (Macht), a force, a positing of authority," originating then in a moment of "privilege ... prerogative," of sovereignty, before which no justice, neither of retribution nor distribution, takes place, but only expiationthe seeking of forgiveness, the making of atonement. The possibility of interruption hence lay only in something entirely distinct, divine violence, the violence of God, opposite in every respect to the mythic violence of the gods, which "instead of founding law ... destroys it." 35

It would be on the idea of a Messianic cessation that Benjamin founded the tie between the essence of revolution and the idea of absolute judgment, utter transformation, and subjugation of prior injustice. ${ }^{36}$ To achieve the tie, Benjamin jerked profane temporality into the realm of sacred time. But he did not leave it there. ${ }^{37}$ Thus at the end of "Critique of Violence," Benjamin can write that "on the suspension of law with all the forces on which it depends as they depend upon it, finally therefore on the abolition of state power, a new historical epoch is founded" because "if the existence of violence outside the law, as pure immediate violence [that is, divine violence], is assured, this furnishes the proof that revolutionary violence, the highest manifestation of unalloyed violence by man, is possible, and by what means." 38 Revolutionary justiceinterruption, cessation — was possible through the actions of men.

What, one might ask, has all this to do with Brecht, Conrad, and Blake? To contend for their salience, I will proceed in order. The exercise itself is an attempt at constellation: that is, an attempt to seize hold of the conjunction that I will argue obtains among them and complete it by folding our "now" into its midst. This is assuredly and obviously not an exercise in what I have called historical positivism-in explaining these subjects and their observations 
by assigning them their appropriate contextual locations in a temporal continuum. Rather, it is to conjoin them, and in doing so offer a glimpse of what may concretely be found in Benjamin's philosophy of history; and to offer us--who are also conjoined-the chance to experience something of the stir that Proust says unlocked his mind when he dunked his madeleine in a cup of tea and brought "the whole of Combray and of its surroundings" into being. ${ }^{39}$ In this conjunction of texts, in short, there exists an opportunity to "hack in" to historical time and reshape it on Benjamin's terms so that we can, in turn, imagine historical incarnations of revolutionary justice. ${ }^{40}$

\section{BRECH T}

Threepenny Novel is already an expression of constellation, being the point of meeting, the folding together, of works from distinct eras: the Novel itself, written in the I930s; Brecht's own Threepenny Opera, finished eight years before; and John Gay's early-eighteenth-century satire of Whig corruption, The Beggars Opera, which Brecht had deftly inserted into the I920s. Most of us will know something of Threepenny Opera and its dramatis personae-the gangster Macheath, better known to American audiences as Mack the Knife; his lover Polly Peachum; and her father, Jonathan Peachum, king of the beggars. Threepenny Novel has the same central characters and the same general plot but is a major revision and expansion. Like Threepenny Opera, it deliberately convolutes time - early Victorian England, the late nineteenth century, Brecht's present. It is set in a Dickensian London of beggars and their petty crime, but the police have tanks and barbed wire and Maxim guns and the Boer War is well under way. Grand corruption is afoot, business and crime blur in war profiteering, Polly goes to the cinema, manners are decidedly modern. Both the setting and the folding of time are crucial: Threepenny Novel narrates a transformation from old to new in the ways of doing crime and businessfrom the petty beggarly ways of Jonathan Peachum to the ways of MacHeath. Between them it squeezes the London masses, the constant multitude of beggars and impoverished shopkeepers, soldiers drowning in rotten ships, and gangsters chased by police whose chief is in the pay of their boss. ${ }^{41}$

The legal order of Threepenny Novel has no existence apart from what Brecht actually depicts; it arises in the competition between Peachum and MacHeath, between the old ways of crime and the new. MacHeath the 
gangster has moved with the times, and become a man of business. His is the way of the future. ${ }^{+2}$ Peachum eventually sees the light and joins MacHeath in "a gentleman's agreement" that sanctions the distribution of the spoils." The agreement produced by their struggle establishes the legal order that will prevail. "Bourgeois legality and crime ... are, by the rules of the crime novel, opposites," Benjamin writes in a commentary on Brecht. "In this crime novel the actual relation between bourgeois legality and crime is presented."

And what of the masses? For a moment they stand in-between, where temporal succession is unsure, where the continuum can explode, where revolutionary justice may obtain. For Threepenny Novel ends - although not quite - in a "Day of Judgment" dreamed by one of the multitude, a wounded soldier by the name of George Fewkoombey, who has returned a cripple from the Boer War. ${ }^{45}$ In Fewkoombey's dream the past flashes up and is recognized. ${ }^{46}$ "After the years of misery came the day of triumph. The masses arose; shook off at last their tormentors ... finally gave up all hope, and won the victory. Everything was changed." The moment of justice arrives. "There could be no question of the judgment day coming at the end of all life, because, after all, it was to be a prelude to life. Before this great judgment had taken place, there could naturally be no talk of real life." It was to be "the greatest arraignment of all times ... the only really essential, comprehensive and just tribunal that has ever existed." ${ }^{18}$ It would judge "not only the living, but also the dead; all who had in any way wronged the poor and defenceless." The proceedings would last hundreds of years. The poorest and most defenseless of all, Fewkoombey, would be the judge, "because no one can stop a dreamer from getting what he wants." 49

But the moment passes, time begins anew. ${ }^{\text {xi }}$ In a trice, the dreamer is awoken, arrested, charged, condemned, and hanged." "Ever upwards!" exclaims the triumphant MacHeath in his final appearance. "Per aspera ad astra!" 52 The new legal order has begun. The masses give their approval..$^{33}$ They have risen once, if only in their dreams. Now they must look to themselves. And now Threepenny Novel ends. ${ }^{34}$

\section{CONRAD}

Brecht's London in Threepenny Novel is Conrad's London in Heart of Darkness. Conrad's London is a "monstrous town," where people live out their lives performing "monkey tricks" amid "neighbours ready to cheer you or 
to fall on you, stepping delicately between the butcher and the policeman, in the holy terror of scandal and gallows and lunatic asylums." 55 The city sits like a spider at the conjunction of institutions, discourses, and oceanic and riverine connections that entangle the entire early-twentieth-century world in the trails that attach dark colonized hinterlands to dark metropolitan hearts"waterway[s] leading to the uttermost ends of the earth." 56

Heart of Darkness tells of the harvesting of ivory from Africa by an entity known simply as "the Company." The tale is told to an audience of eponymous listeners whom we know only as "The Director of Companies ... The Lawyer ... [and] The Accountant." ${ }^{\text {"T7 }}$ The listeners stand for the combination of particular structures of production and extraction with particular forms of knowledge and expertise. "The Director of Companies was our captain and our host" says one of the listeners. "We ... affectionately watched his back." 58 What these structures and forms have in common in their swarming together is their common will to improve. In Threepenny Novel the legal order emerges from the resolution of competition between old and new forms of crime and business; here the fount of order is what the storyteller, the curiously disembodied Marlow, identifies as "devotion to efficiency."

The conjunction of structures and forms constructs the world that Marlow describes. Law_ "an insoluble mystery from the sea"-enchains the Company's African labor, whether by straightforward criminalization or by "the legality of time contracts." 60 Accountancy_-apple-pie" bookkeepingassures the Company's ascendancy in "the merry dance of death and trade." Constant distractions gnaw at efficiency- "the groans of th[e] sick," the heat, the babble of uncouth natives. The greatest distraction of all is Kurtz, the legendary chief of the Company's "Inner Station." Once the apple of the Company's eye, the "emissary of pity and science" it sent to transform the inhabitants of the inner territories with the disciplines of progress, ${ }^{62}$ Kurtz becomes the greatest obstacle to the Company's designs. He revolts against its purposes, turns himself into a primitive sovereign, an upriver barbarian monarch who scorns the Company's "peddling" and roams "beyond the bounds of permitted aspirations." The Company is greatly relieved at his death. ${ }^{63}$

Against the Company and its expertises of "efficiency," of "pity and science and progress," the rebellious Kurtz stands for justice. Kurtz makes the claim himself - "I want no more than justice"; ${ }^{64}$ he marshals a sovereign's violence in his claim's service; ${ }^{65}$ and his last words, whispered "during that supreme moment of complete knowledge" before death, deliver absolute judgment. ${ }^{66}$ 
This is not of course the justice of liberal political imagination-the justice that is achieved by marshaling law, indistinguishable from the Company's "progress." It is justice akin to Fewkoombey's dream of vengeance, to Benjamin's imagination of justice in its revolutionary incarnation as divine retribution delivered at a Messianic moment. And just as Fewkoombey imagines judgment deliverable only at a moment out of scientific sequential time, of time out of joint, in a dream, so Kurtz's judgment, "all the wisdom, and all truth, and all sincerity," is also delivered at just such a moment, "compressed into that inappreciable moment of time in which we step over the threshold of the invisible." ${ }^{67}$ And like Fewkoombey, it is betrayed. ${ }^{68}$ Indeed, Marlow's story, which in its entirety remorselessly delivers judgment (as much on himself, for his betrayal, as on what he recounts), is told as if it were itself a dream, or at least dreamlike; a recollection that begins and ends in darkness. It sparks suddenly into existence out of nothing, in a moment outside historical time, a fold. ${ }^{69}$ We know this from the very moment Marlow abruptly begins, because in the instant of beginning he declares the fold, the convolution, in a tangle of spaces and temporalities - of London and Africa, of rivers, of long before and eternity and the moment of now, all crystallized as a single constellation: “'And this also,' said Marlow suddenly, 'has been one of the dark places of the earth." His disembodied voice comes out of nowhere. What does he mean? "'I was thinking" he goes on, "of very old times, when the Romans first came here, nineteen hundred years ago - the other day. . . . Light came out of this river since-you say Knights? Yes; but it is like a running blaze on a plain, like a flash of lightning in the clouds. We live in the flicker - may it last as long as the old earth keeps rolling! But darkness was here yesterday." And so forth. ${ }^{70}$

\section{BLAKE}

Conrad's London in Heart of Darkness is Blake's London. So is Brecht's. For the multitude, Brecht's London was a place of destitution, oppression, and cynicism. So was Conrad's - a "monstrous" place, remember, where people performed "monkey tricks" to survive, picking their way between butchers and policemen, lunatic asylums and the gallows. Each made London the rotting heart of empire. And each counterposed his story in time to what Benjamin calls Messianic time. For justice, in Brecht and Conrad, we can say, exists 
"in the flicker" outside historical time, far distant from progress and science and law. ${ }^{\prime 1}$ What of Blake?

We encounter William Blake's London at its fevered revolutionary climacteric of the early i79os. London was fevered by Jacobin "rights talk," fed by the Enlightenment, but Blake was no Enlightenment scion. Though he hated state and church as much as any Jacobin, "it did not follow," says E. P. Thompson in Witness Against the Beast - his last book and perhaps the book truest to himself - "that humanity's redemption . . . could be effected by a political reorganization of these institutions alone. There must be some utopian leap, some human rebirth, from Mystery to renewed imaginative life."72

Walter Benjamin's conception of revolution very deliberately reached for the sacred temporality of divine violence, of judgment and redemption, for its own "utopian leap." 73 As he put it, in the first of the Theses: "[Historical materialism] can easily be a match for anyone if it enlists the services of theology, which today, as we know, is wizened and has to keep out of sight"; in the last, that "every second of time" is "the strait-gate through which the Messiah might enter." 74 Blake's theology_eschatological and antinomianwas of course neither wizened nor out of sight, but loomed large in his every depiction of humanity. Thompson writes of Blake's poem "London" that it is "instantly available," that it requires no interpreter. "The images are selfsufficient within the terms of the poem's own development. Every reader can, without the help of a critic, see London simultaneously as Blake's own city, as an image of the state of English society and as an image of the human condition." 75 But this is no mere social commentary. Blake's poem bears witness against the Beast.

I wander thro' each charter'd street,

Near where the charter'd Thames does flow.

And mark in every face I meet

Marks of weakness, marks of woe.

In every cry of every Man, In every Infants cry of fear, In every voice: in every ban, The mind-forg'd manacles $I$ hear

How the Chimney-sweepers cry Every blackning Church appalls, 
And the hapless Soldiers sigh,

Runs in blood down Palace walls

But most thro' midnight streets I hear

How the youthful Harlots curse

Blasts the new-born Infants tear

And blights with plagues the Marriage hearse ${ }^{76}$

The London of Blake's poem was Patrick Colquhoun's London-the London, that is, of the Police of the Metropolis (1796), the world's greatest commercial city, the riverine heart of an imperial political economy, inhabited by a laboring population disciplined by the sciences of magistracy. This London, Blake's "London," is Hell on Earth. Everything_-every inhabitant, every street, the river itself, the entire city-has been "charter'd"; that is, contracted out, hired, expropriated, absorbed into an unrelieved commerce in things and people. Hire leaves its corruptions evident in every face and activity, heard in every voice. The mark on every face is the mark of the Beast. We are in the realm of the Antichrist. Humanity is fallen, laid low by the charters and bans of the "blackning" church and blood-drenched king, clasped all in mind-forg'd manacles, from barrow boy to prostitute. ${ }^{7}$

Blake's judgment flayed every fragment of Colquhoun's London. Still, he ends not in despair but with a curse, a snarl of anger. It is the city that has been sold out, not the city that has done the selling. For always alongside London as Hell on Earth, Blake glimpses another city, Jerusalem, immanent, the spectral London that "could also be the millennial city, of that time when the moral and self-righteous law should be overthrown, and the Multitude return to Unity." 78 Blake's only church was the Church of the New Jerusalem; his spectral London was humanity redeemed; its time, of course, was Messianic. The unity to which the multitude returned, at the end, was that of release from the order of the profane, the unity of the City of God. ${ }^{79}$

\section{EN D}

At the outset, I indicated my purpose would not be to assign these subjects to their appropriate locations in a temporal continuum - to engage in explanation by temporal contextualization. Conventionally, we do this at the beginning; we create a "frame" for our narratives of people and events that 
establishes an explanatory context for what will follow. Subjects then become illustrations of an explanation. In part, this essay is an exercise in critique of doing exactly that.

So, really, I should simply leave it at that. But to do so would be irresponsible. After all, the essay began by wondering what literature could teach contemporary legal historians about history as a practice. It has examined time and justice to ask what literature as a form can do that history cannot, and whether that knowledge might change the practice of history. I chose Benjamin as guide because he stands so precisely at the exact locus of this intersection: literary critic, philosopher of history. It seems appropriate, therefore, to try to sketch my own standpoint in the literal constellation of place and time and subjects that I have discussed, so as to bring out what I see lying there so that it can in turn be discussed, criticized, or ignored.

In an article published a few years ago, Silvana Caporaletti (of the University of Lecce, Italy) reads in the literature of the early twentieth century a reaction against the later nineteenth century's triumphant epoch of scientific explanation, whose crowning achievements we might say pronounced the death of life. The enunciation of the second law of thermodynamics - that "the entropy of an isolated system not in equilibrium will tend to increase over time"-seemed to mean the irreversible death of the universe; Darwinian evolution seemed to mean the death of God; the apparent subjection of human life to "impersonal laws... utterly indifferent to its presence" seemed to mean the death of spirit and will. ${ }^{80}$ In discussing the reaction, Caporaletti points in particular to the intense interest in temporality and memory sparked by Henri Bergson (whose work we have already-indirectly-encountered ${ }^{81}$ ). In Time and Free Will (1889) Bergson contrasted "scientific" time--linear and sequential, mere extension, not a dimension of reality at all but the artifact of a need to measure — with what he called "durée réelle," interior and subjectively experienced time, "a spherical dimension where past, present and future coexist and continually interact, shaping each other." A few years later Bergson's better known Matter and Memory (1896) drew a similar distinction between conscious memory - active reflection - and "mémoire réelle," by which Bergson meant "unconscious memory where past events are preserved in their original intensity." M. Forster and James Joyce, but as she notes, Bergson's ideas about time and memory informed the passions of many of their contemporaries--T. S. Eliot, for one, and obviously Proust, with whom we began. 
It would be quite absurd, of course, to march these many intellects beside each other as a phalanx of uniformity, sharing a single reaction, expressing in response the same idea. Better to think of them as a milling crowd, upon whom certain urgent concerns_- "current amazements"--were having a variety of impacts. Both Brecht and Conrad, I think, can be spotted in this crowd, and obviously Benjamin himself is there too, the flâneur. ${ }^{83} \mathrm{I}$ have added William Blake to the mix, however, to underline the danger in approaching certain ideas as if they were "produced" at a particular time by a context. Blake, after all, had no need of Bergson. He already knew what Bergson would discover.

And what of justice? I can offer a similar sketch and a similar caution. Justice, Roger Berkowitz tells us in a recent book, has fled our modern world. Science aspired to renew law with the language of reason without vitiating law's claims to transcendence. But instead, science hollowed law out, creating in its place mere "technique." Justice, in other words, fled, as the same nineteenth-century onrush of science that was remaking life simultaneously remade law in its own calculated image. Of course, justice is still very much part of our vocabulary, but as Berkowitz writes, when we talk justice we do not mean "Antigone's burial of Polynices, or God's divine judgment that struck Ananias dead." Our talk of justice is of justice as an outcome of positive law, a creature of its rules and procedures, a justice of "fairness" or "efficiency" or "balance" produced by technique. These are but Earth-bound remnants, says Berkowitz, pallid residues of the real thing. ${ }^{84}$

Berkowitz sees legal modernity, from which justice flees, by which its residual has been appropriated, as in origin an Enlightenment project. Legal modernity is - to quote his book's wry title- "the gift of science." This "periodization" means that now we can squeeze Blake under the same explanatory umbrella as the others, for the force beating on Blake's antinomian faith was, of course, the mechanistic epistemology of Newton and Locke. ${ }^{85}$ Still, can this historical temporalization, this context-the rise of "science" explain the flight of justice? Justice had fled before: "Terras Astraea reliquit," Ovid tells us at the very beginning of the first millennium; in the early $1590 \mathrm{os}$ Shakespeare repeats him, word for word, in Titus Andronicus, a play precisely about law and justice. "She's gone," says Titus, in Act IV; "she's fled." Justice returns in Act V, though not for long. ${ }^{87}$ My point is that justice's time cannot be "placed," it does not flee and return on causal cue. Justice's time is time "out of joint," as Brecht, Conrad, and Blake all had it, and as Benjamin knew in making revolutionary justice Messianic. 
One final point. Justice, says Berkowitz, is transcendent, ineffable. It "resists precisely what modern man most craves: definition." I agree. (It is that craving that will lead some to think it bizarre that-for example-I make Kurtz stand for justice in Heart of Darkness, when what Kurtz stands for seems so utterly unlike anything that we would call justice today.) But Berkowitz fails to follow his own advice; he penetrates the ineffable, and defines justice. Justice is that familiar "higher good"; it is human dignity, nobility, the acme of morality, and ethical perfection. ${ }^{88}$ Indeed that may well be. It is also vengeance, even terror, as God demonstrates when he destroys Korah and all his followers, and then slaughters I 5,000 Israelites, all for Korah's antinomian defiance of Mosaic theocracy. ${ }^{89}$ My point is, the transcendent defies expression; that is what ineffable means.

Perhaps for that very reason "modern man" might actively prefer law to justice. There is, after all, nothing necessarily "fair" or "efficient" or "balanced" in Benjamin's jurisprudence of revolution. ${ }^{90}$ Justice is not predicable; nor is revolution. In Benjamin's Leibnizian terms, both are monads. They contain all their predicates. One can know that they will unfold, but never precisely how.

1. Lawrence Douglas, "Discursive Limits: Narrative and Judgment in Billy Budd," 27 Mosaic, Dec. 1994, at 142 (citing James Boyd White, "Law as Rhetoric, Rhetoric as Law: The Arts of Cultural and Communal Life," 92 University of Chicago Law Review $68_{4}$ (1985)); see generally 14I-6o. See also Wai Chee Dimock, Residues of Justice: Literature, Law, Philosophy (Berkeley: University of California Press, 1996), 1o (Literature is "the textualization of justice ... the historicization of justice . . . a testing ground no jurist or philosopher can afford to ignore.").

2. Richard Weisberg, Poethics: And Other Strategies of Law and Literature (New York: Columbia University Press, 1992), ix, x, 3, 34. See also Richard Weisberg, The Failure of the Word (New Haven: Yale University Press, 1984).

3. "The preeminent contribution of literature to our substantive vision of law," Weisberg continues, is "that sound and sense, form and substance, are united in legal language." Poethics, supra note 2, at 34. See also Gary Minda, "Crossing the Literary Modernist Divide at Century's End: The Turn to Translation and the Invention of Identity in America's Story of Origins," in Michael Freeman \& Andrew D. E. Lewis, eds., Law and Literature: Current Legal Issues Volume 2 (Oxford: Oxford University Press, 1999), 331-4I, 352-54. The point of origin for this argument, and in some ways the point of origin for the modern field of law and literature, is James Boyd White, The Legal Imagination: Studies in the Nature of Legal Thought and Expression (Boston: Little, Brown, 1973).

4. Brook Thomas, Cross-Examinations of Law and Literature: Cooper, Hawthorne, Stowe, and Melville (Cambridge and New York: Cambridge University Press, 1987), 252. Law's intrinsic logic is more immediately apparent, Thomas argues, integral to the way the juridical field understands itself and is 
apprehended by others. Structurally, however, literature is relatively more autonomous than law. The reason is simple: "Law is a vital part of the manner in which a society is governed; literature is not."

5. Id. at 252, 4-6. On "structural coupling," see Gunther Teubner, "How the Law Thinks: Toward a Constructivist Epistemology of Law," 23 Law \& Society Review 727 (1989); Alan Hunt, "Foucault's Expulsion of Law: Toward a Retrieval," 17 Law E Social Inquiry I (1992). "Hack into" may seem an unnecessarily violent metaphor; in fact, I use it in its current code-hacking sense of gaining entry by unorthodox, unauthorized means. Still, the hint of violence should not necessarily be entirely ignored. See also infra, note $4^{\circ}$. See also Walter Benjamin, "The Destructive Character," in Peter Demetz, ed., Walter Benjamin, Reflections: Essays, Aphorisms, Autobiographical Writing (New York: Schocken, 1978), 301 [hereinafter Reflections].

6. Poethics, supra note 2, and Thomas, supra note 4 , are but two (foundational) examples. See also the collected essays in the Mosaic symposium Adversaria: Literature and Law (Dec. 1994).

7. For a recent example, see Alfred S. Konefsky, "The Accidental Legal Historian: Herman Melville and the History of American Law," 52 Buffalo Law Review 1179 (2004).

8. For a critique of history's default settings, see Christopher Tomlins, "The Strait Gate: The Past, History and Legal Scholarship," 5 Law, Culture and the Humanities 21 (2009).

9. As far as I am aware, none of the three have occupied a place of any great prominence in the law/ literature canon. For an unsystematic guide to what has engaged scholars in the field, see, for example, Julie Stone Peters, "Review Essay: Law and Literature," 9 Cardoz̧o Studies in Law and Literature 259 (1997); Judith Koffler, "Review Essay: Three Looking Glasses for Law and Literature," Io Cardozo Studies in Law and Literature 69 (1998). Thomas, supra note 4, exemplifies the use of canonical texts; Richard Weisberg discusses and defends a "Great Books" canon for law and literature in Poethics, supra note 2 , at $117-23$.

10. Christopher Tomlins, "The Threepenny Constitution (and the Question of Justice)," 58 Alabama Law Review 979 (2007), and "Afterword: Constellations of Class in North America and the Atlantic World," in Simon Middleton \& Billy G. Smith, eds., Class Matters: Early North America and the Atlantic World (Philadelphia: University of Pennsylvania Press, 2008). Other recent work of mine that informs this essay includes "The Strait Gate," supra note 8, and "To Improve the State and Condition of Man: The Power to Police and the History of American Governance," 53 Buffalo Law Review 1215 (2005).

11. Bertolt Brecht, Threepenny Novel, trans. Desmond I. Vesey \& Christopher Isherwood (New York: Grove Press, 1956); Joseph Conrad, Heart of Darkness (1902), available at http://etext.virginia.edu/ toc/modeng/public/ConDark.html (Signet Classics reprint: New American Library) (last accessed March 8, 2009); William Blake, "London," in Songs of Innocence and Experience, Shewing the Two Contrary States of the Human Soul (1794), available at The William Blake Archive, www.blakearchive.org/ blake/indexworks.htm (last accessed March 8, 2009).

12. As I hope to show, Benjamin's jurisprudence of revolution (revolutionary justice) is inseparable from his interventions in historical materialism, which, though Marxist in inspiration, are notable for their rejection of orthodox (Third International) Marxism's teleologies. "Three moments must be made to penetrate the foundations of the materialist view of history," he wrote in the course of preparing "Theses on the Philosophy of History." They were "the discontinuity of historical time; the destructive power of the working class; the tradition of the oppressed." Quoted in Alex Callinicos, Making History: Agency, Structure and Change in Social Theory (Leiden and Boston: Brill, 2004), 208-09. Each moment induces a fundamental upheaval in received conceptions of historical time. The first, "discontinuity," assails orthodox historical materialism's bow to the Enlightenment ideal of historical progress. For the continuum of "forwards" it substitutes a radical uncertainty about the course of historical time, a critique of the very idea of historical time itself, and a conception of revolution as the complete interruption of time. The second, "destructive power," identifies the working class as the agent of interruption, stressing the working class's revolutionary consciousness of its capacity to "make the continuum of history explode." The third, "the tradition of the oppressed," unites the first and second in founding 
revolutionary consciousness on memory - but memory of a particular kind, a galvanic conjunction between now and then. Memory is the key to formation of historical knowledge "not [in] man or men but the struggling, oppressed class itself." And historical knowledge is how the oppressed come to know themselves as "the last enslaved class" and as "the avenger that completes the task of liberation in the name of generations of the downtrodden." Together, these three fundamental interventions in historical materialism swerve it off the path of progress and into the eschatology of redemption. See variously Walter Benjamin, "Theses on the Philosophy of History," Theses 5, 6, 11, 12, 15, and 17 [hereinafter "Theses"], in Hannah Arendt, ed., Walter Benjamin, Illuminations: Essays and Reflections (New York: Schocken Books, 1969) [hereinafter Illuminations]; Benjamin, "The Destructive Character," in Reflections, supra note 5 , at $301-03$.

Benjamin's conception of revolutionary justice is embedded in the theology of messianic expiation and redemption. The more of Marx he read, the more he saw the same in Marx.

Wai Chee Dimock attributes to Marx a conception of justice as "objective adequation" (recuperation) grounded on a materialist epistemology (i.e., "the translatability of the economic into the legal, the political and the social") that is precisely the expression of classless society achieved teleologically through the proletariat's full-grown achievement of metonymic "completion"-integral wholeness, revolutionary transformation from part into whole-as the ultimate actualization of all humanity, wherefrom the just society emerges in the form of the classic slogan "from each according to his ability, to each according to his needs." Dimock, supra note 1, at 57-74.

Benjamin saw matters differently. There was nothing teleological in Marx's conception of classless society or its emergence. Rather, "In the idea of classless society, Marx secularized the idea of messianic time." It was German social democracy (the SDP) that had converted classless society from an idea to an ideal, and, by defining it in the process as "an infinite task," had substituted a neo-Kantian for a messianic meaning. Once this had happened, "once the classless society had been defined as an infinite task," historicist time, "empty and homogenous," had taken over from the messianic: "Time was transformed into an anteroom, so to speak, in which one could wait for the emergence of the revolutionary situation with more or less equanimity." Teleology, that is, lay in the philosophy of the SDP, not in Marxist materialism. In the latter, "there is not a moment that would not carry with it its revolutionary chance." Historical materialism searches out the presence of that revolutionary chance, "the presence of a messianic force in history." Materialism did not predict. "Whoever wishes to know what the situation of a "redeemed humanity" might actually be, what conditions are required for the development of such a situation, and when this development can be expected to occur, poses questions to which there are no answers." What could be answered was the question of how to rescue what social democracy had cast out:

Three basic concepts can be identified in Marx's work, and its entire theoretical armature can be seen as an attempt to weld these three concepts together. They are the class struggle of the proletariat, the course of historical development (progress), and the classless society. The structure of Marx's basic idea is as follows: Through a series of class struggles, humanity attains to a classless society in the course of historical development. But classless society is not to be conceived as the endpoint of historical development.

This was the erroneous conception from which "Marx's epigones" derived (among other things) their teleological notion "of 'the revolutionary situation,' which, as we know, has always refused to arrive." Rescue, Benjamin concluded, required that "a genuinely messianic face . . . be restored to the concept of classless society ... in the interest of furthering the revolutionary politics of the proletariat itself" and, one might add, in the interests of furthering a conception of revolutionary justice that was other than "objective adequation." Redemption was not recuperation. "The Messiah comes not only as redeemer, he comes as the subduer of Antichrist." Revolutionary justice was expiatory. 
See Walter Benjamin, "Paralipomena to 'On the Concept of History," (fragments written in 1940, unpublished in Benjamin's lifetime), in Howard Eland \& Michael W. Jennings, eds., Walter Benjamin. Selected Writings, vol. 4, 1938-40 (Cambridge, MA: Harvard University Press, 2003), 401-03 [hereinafter Selected Writings]; "Theses," supra, at Thesis 6, 255; Walter Benjamin, "Critique of Violence," in Reflections, supra note 5, at 297, 300. For arguments in favor of neo-Kantianism and an attempt (I think unsuccessful) to align Benjamin with neo-Kantianism, see David Luban, Legal Modernism (Ann Arbor: University of Michigan Press, 1994), 82.

13. I discuss Marxist theories of law in Christopher Tomlins, "How Autonomous Is Law?" 3 Annual Review of Law and Social Science 45 (2007). See also Bob Jessop, "On Recent Marxist Theories of Law, the State, and Juridico-Political Ideology," 8 International Journal of the Saciology of Law 339 (1980). To give one example of Benjamin's difference, virtually all Marxist theories of law center on an extended engagement (with varying degrees of success) with the base/superstructure relation. A Marxist theory of law inflected by Benjamin's philosophy of history can simply elide the relation, in that in many ways Benjamin treats "base" as an effect of "superstructure," an interior encountered empirically only through its exterior. See, for example, his intense stress on the "historical image" as "dialectics at a standstill," his exchanges with Adorno on Marxist theory, his famous essay (which exists in several versions and translations) on "The Work of Art in the Age of Its Technological Reproducibility," and his clear interest in the work of Karl Korsch, who criticized Marx's followers for detaching his materialist conception of history from its "specific application" and elaborating it into "a universal ... sociological theory," and who stressed that Marx's terminology of base and superstructure was figurative only, intended "as a wholly undogmatic guide to research and action." See Walter Benjamin, "Convolute $\mathrm{N}$-On the Theory of Knowledge, Theory of Progress," in The Arcades Project (Cambridge, MA: Harvard University Press, 1999), $456-88$, notably $460 \mathrm{~N} 1 \mathrm{a}, 6-\mathrm{N}_{12}, 8 ; 462 \mathrm{N2a}, 3 ; 462 \mathrm{~N} 2 \mathrm{a}, 4 ; 4{ }_{3} \mathrm{~N}_{3}, \mathrm{I}$; ${ }_{4} 84 \mathrm{~N}_{17} ; 4_{84}-85$ N 17 a [hereinafter Arcades Project]; "Exchange with Theodore W. Adorno" (1935) in Selected Writings, supra note 12, at vol. 3, 50-67; "Exchange with Theodore W. Adorno" (1939), in Selected Writings, supra note 12, at vol. 4, 99-115, 200-214; Walter Benjamin, "The Work of Art in the Age of Its Technological Reproducibility," in Selected Writings, supra note 12, at vol. 3, 101-33 (second draft), vol. 4, 25I-83 (third draft). The third draft is also available as "The Work of Art in the Age of Mechanical Reproduction," in Illuminations, supra note 12, at $217-51$.

14. For another (related) facet see infra, note 70 , on monads.

15. Gilles Deleuze, The Fold: Leibniz and the Baroque, trans. Tom Conley (Minneapolis: University of Minnesota Press, 1993), xi. Deleuze, at 4, introduces the basic point as follows: "[Christiaan] Huygens develops a Baroque mathematical physics whose goal is curvilinearity. With Leibniz the curvature of the universe is prolonged according to three other fundamental notions: the fluidity of matter, the elasticity of bodies, and motivating spirit as a mechanism."

16. See Henri Bergson, Time and Free Will, an Essay on the Immediate Data of Consciousness (New York: Macmillan, 1910), 75 (originally published as Essai sur les données immédiates de la conscience (1889).

17. Walter Benjamin, "The Image of Proust" (1929), in Illuminations, supra note 12, at 201. See also "On Some Motifs in Baudelaire," in Selected Writings, supra note 12, at vol. 4, 314-16.

18. Originally expressed in English translation as Remembrance of Things Past, more recently as In Search of Lost Time.

19. Marcel Proust, Remembrance of Things Past, vol. 1, Swann's Way, trans. C. K. Scott Moncrieff (New York: Random House, 1934), $54-57$.

20. Id. at 57 -58. Benjamin reciprocates in "The Storyteller: Observations on the Works of Nikolai Leskov" (1936), in Selected Writings, supra note 12, at vol. 3, 148, 154 .

2I. See, e.g., Gordon S. Wood in reply to Calvin H. Johnson, 53 New York Review of Books 8 (May II, 2006), available at http://www.nybooks.com/articles/18981 (last accessed March 8, 2009).

22. Compare Hannah Arendt on "the primacy of narrative," as interpreted by David Luban, supra note I2, at 179, particularly 198-204. 
23. Benjamin, "Theses," supra note I2. Though composed as such between December I939 (after Benjamin's return to Paris from three months of internment as an enemy alien) and May 1940, the Theses develop and distill themes apparent in Benjamin's writing for more than a decade. Benjamin himself remarked that he had been "[keeping] them safe for almost twenty years." See "Chronology, 1938-1940," in Selected Writings, supra note 12, at vol. 4, 439-4I. Callinicos, Making History, supra note I 2, ar 208, calls the Theses "an intransigent and, given the context in which they were written, moving affirmation of the revolutionary potential of the working class," and draws attention to Michael Löwy's description: "one of the most radical, path-breaking and seminal documents of revolutionary thought since Marx's 'Theses on Feuerbach.” Michael Löwy, “'Revolution' Against 'Progress': Walter Benjamin's Romantic Anarchism," 152 New Left Review, July-Aug., 1985, at 42, 59.

24. "Theses," supra note 12 , at Thesis 6 and Thesis 5 . For productive use of the Theses to clarify the critical conjunction of literature, law, and history, see, e.g., Thomas, supra note 4, at 253-55, and, more extensively, Brook Thomas, The New Historicism and Other Old-Fashioned Topics (Princeton: Princeton University Press, 1991), 109-15, 173-78, 210-11. In Cross-Examinations, Thomas cites Benjamin's philosophy of history in response to Sandy Levinson's somewhat plaintive question-directed at literary theory and legal history- "What does one do, then, when studying opinions, if one gives up the enterprise of determining whether they are or not 'correct'? Are cases simply historical fragments which should be studied for insight into the ideology of the time?" Sanford Levinson, "Law and Literature," 60 Texas Law Review 386 (I982). As Thomas points out, in effect Levinson here takes historical to mean historicized. One might add that far from fragments left adrift in the ideology of their time, "cases" are narratives - stories - by which the past can "flash up" in the midst of the present, but this is in fact a point subsequently well made in The New Historicism, supra, at $175-77$, with the assistance of Benjamin's essay "Literary History and the Study of Literature" (1931), in Selected Writings, supra note 12, at vol. 2, pt. 2, 459, which concludes:

What is at stake is not to portray literary works in the context of their age, but to represent the age that perceives them - our age - in the age during which they arose. It is this that makes literature into an organon of history; and to achieve this, and not to reduce literature to the material of history is the task of the literary historian.

For an essay that attempts to perform such a task, see Norman W. Spaulding, "Constitution as Countermonument: Federalism, Reconstruction, and the Problem of Collective Memory," 103 Columbia Law Review 1992 (2003).

Thomas, in The New Historicism, supra, at II4-15 (also Luban, supra note 12 , at 276-78), seems to me to elevate the redemptive component of Benjamin's philosophy of history over its revolutionary materialism, rather than treat them, too, as a critical conjunction. The effect in my view is to make Benjamin's philosophy of history less historical (and to alter its politics). For a more recent instance, see Amy Kapczynski, "Historicism, Progress and the Redemptive Constitution," 26 Cardozo Law Review 1041 (2005). I discuss the essays by Spaulding and Kapczynski at greater length in "The Strait Gate," supra note 8.

25. Benjamin's target in the Theses is the old (Rankean) historicism that expresses past, present, and future as sequence and, in positivist mien, situates phenomena in that sequence as - in Constantin Fasolt's memorable phrase - "butterflies on pins." See Constantin Fasolt, The Limits of History (Chicago: University of Chicago Press, 2004), 15 r. But we have seen the more or less parallel development since the early 1980 of new (critical) historicisms in both literature and law; one may ask to what extent Benjamin's critique of the old applies also to the new.

Both new historicisms effectively criticized the teleological tendencies of old historicism. Both took "the historical and cultural specificity of ideas" (Thomas, The New Historicism, supra note 24, at xi) to underline the contingency of meaning attributable to legal and literary texts across time (if, 
in Robert Gordon's words "the meanings of words and actions are to some degree dependent on the particular social and historical conditions in which they occur"-Robert W. Gordon, "Historicism in Legal Scholarship," 90 Yale Law Journal IOI 7 n.I (1981) - that dependence must necessarily disturb the timelessness, hence consistency of meaning that orthodoxies attribute to texts). Both found opportunities and openness to exist within contingency. Both then pushed further to a totalized contingencyindeterminacy-that dissolved the separation of text from context. Critical legal history attacked every prior attempt to stabilize historical context and its relationship to law as "evolutionary functionalism" (Robert W. Gordon, "Critical Legal Histories," 36 Stanford Law Review 1-2 (1984)). Critical analysis of doctrine exposed, at least to its own satisfaction, not only the absence of any determining relationship between law (particular rules and processes) and society (particular social practices, structures, or other discourses), or vice versa, but also the absence of any determinate meaning attributable to the rule considered on its own terms, stemming from its own internal contradictions (Tomlins, "How Autonomous Is Law," supra note 13, at 58). In literature, similarly, "new historicism" held there could be "no predetermined context in which we can place a text in order to understand it historically" (Thomas, The New Historicism, supra note 24, at 38-39, 44-45; but see Dimock, supra note I, at 77-79).

In the totalized contingency at which both new historicisms arrived, one can discover no longer any trace of explanation - which was, after all, what both set out to attempt - but instead an aesthetic of "complexity" - an infinite plurality of outcomes that will enable one to provide whatever history for one's text one could desire. Complexity's emphases-complete contingency, perpetual contest, and continuous renegotiation-are at one with the indeterminacy thesis, which is perhaps why Gordon finds promise in "virtually all history" when applied to law. See Robert W. Gordon, "Foreword: The Arrival of Critical Historicism," 49 Stanford Law Review 1024, 1027-30 (1997). It is unclear, however, what complexity/indeterminacy produces, other than more of itself, which is frankly disempowering (for an acknowledgement of this outcome, see Robert W. Gordon, "The Past as Authority and as Social Critic: Stabilizing and Destabilizing Functions of History in Legal Argument," in Terrence ]. McDonald, ed., The Historic Turn in the Human Sciences (Ann Arbor: University of Michigan Press, 1996), 365 . Turning history into a field of play, the new historicisms risk turning their practice into an exercise in irresponsibility. For, apart from anything else there is a certain "impertinence" in the critical intellectual's celebration of the liberating promise of contingency and indeterminacy, the injunction to realize there is opportunity in plasticity. The vast majority of the population of the world needs no instruction in indeterminacy. Its "normal experience ... has been for centuries that of unstable, rurbulent, uncertainty." Francis Barker, The Culture of Violence: Essays on Tragedy and History (Chicago: University of Chicago Press, 1993), I I I.

One might nevertheless argue that the new historicisms' totalized contingency reproduces Benjamin's resistance to "completion." Indeed, incompletion was central to Benjamin's conception of history. "Only a redeemed mankind receives the fullness of its past." "Theses," supra note 12, at Thesis 3 . For this he was criticized by Max Horkheimer, who wrote in 1937 , "[T] he determination of incompleteness is idealistic, if completeness is not comprised within it. Past injustice has occurred and is completed. The slain are really slain ... If one takes the lack of closure entirely seriously, one has to believe in the Last Judgment." Arcades Project, supra note 13, at 471 N8,1. Yet the slain, though really slain, are not thereby rendered no more, but find ways to seek our attention, waiting and hoping for the moment of recognition, of recollection, the shattering constellation of then and now in one "enormous abridgement" ("Theses," supra note 12 , at Thesis 18 ) that was the product of remembrance. Here, then, was Benjamin's answer to Horkheimer: "remembrance ... forbids us to conceive of history as fundamentally a-theological." Last Judgment indeed, when the past became for the first and only time citable in all its moments, and history would end. But this is also the answer to the question whether Benjamin's incompletion has been reproduced in the directionless contingency of the new historicisms. In my view it has not. Just as we cannot read redemption in Benjamin's philosophy of history other than as a revolutionary act, we cannot read incompletion in that philosophy except through its end in revolution. 
26. "Theses," supra note 12 , at Thesis 17.

27. Id. at Thesis 16.

28. Id. at Thesis 9.

29. Benjamin, "Critique of Violence," in Reflections, supra note 5, at 277. The title of Benjamin's essay in German was Zur Kritik der Gewalt (Walter Benjamin, "Zur Kritik der Gewalt," 47 Archiv für Sozialwissenschaft und Sozialpolitik (1920-21)). The original title may be interpreted as differing from the implications of the English translation in two respects: First, and less important, Zur Kritik der Gewale might better be rendered as "On the Critique of ..." or "Toward a Critique of ...". This reinforces the correct sense of Kritik/Critique, which is evaluative rather than condemnatory. Benjamin is undertaking a critique and simultaneously exploring how the critique may be undertaken. His text is perhaps more experimental than the English title implies. Second, and more important, Gewalt can also be translated as "legitimate power" or "authority" or "public force." What is translated as "violence" thus can mean state action to exert pressure, threaten, or coerce in the name of authority, rather than physical onslaught and destruction from any source. See generally Jacques Derrida, "Force of Law: The Mystical Foundation of Authority," in Acts of Religion/Jacques Derrida, ed. Gil Anidjar (New York: Routledge, 2002).

30. Georges Sorel, Reflecrions on Violence, trans. T. E. Hulme \& J. Roth (New York: Free Press, I950). "Critique" appears in the first instance to be a response to Herbert Vorwerk, "Das Recht zur Gwealtanwendung" [The Right to Use Force], I Blätter für Religiösen Soz̨ialismus, no. 4 (1920). See Walter Benjamin, "The Right to Use Force," in Selected Writings, supra note 12, at vol. 1, 231-34.

31. Sorel counterposed the sublime violence of the proletarian general strike-“a revolt pure and simple," a "serious, formidable and sublime" act of the class for itself (Sorel, supra note 30, at 157, 158) - with the manipulations of working class institutions undertaken by parliamentary socialists to produce forms of force and pressure (the "political strike") to their own advantage (id. at, e.g., 93-103, 171-201). He distanced the violence of the proletarian general strike from Jacobinism, emphasizing in fact the continuity of ancién regime, Revolution, and early twentieth-century socialism in a single "theory of the predominance of the State" against which proletarian violence was to be arrayed (id. at 125). Jeremy Jennings comments: "If the object of State force was to impose a social order based upon inequality and exploitation, the purpose of proletarian violence was 'the destruction of that order." It was to be animated "by a conception of war drawn from the ancient Greeks ... unselfish, heroic, disciplined, devoid of all material considerations. It would be informed by ethical values engendering "an entirely epic state of mind."' See Jeremy Jennings, introduction to Reflections on Violence, ed. Jeremy Jennings (Cambridge and New York: Cambridge University Press, 1999), xviii-xix and generally vii-xxi.

32. "Theses," supra note 12 , at Thesis 15 .

33. Note, for example, the concern expressed in Thesis 14 at the necessity of achieving a revolutionary consciousness that did not mimic the past but rather grew out of a dialectical constellation of past and now "in the open air of history." Both were possible; only the latter had the chance of success. (Thesis 14 is Benjamin's reading of Marx's Eighteenth Brumaire of Louis Bonaparte. See Karl Marx and Friedrich Engels: Selected Works (London: Lawrence and Wishart, I970), 96-179. For distinct readings both of the Eighteenth Brumaire and of Benjamin, see Luban, supra note 12, at 279-81, and Thomas, New Historicism, supra note 24, at $112-16$.)

34. Derrida, "Force of Law," supra note 29, at 286. Thus, both may be seen as identifying sublime moments of justice in which finality is achieved. For Sorel, the proletarian general strike is

the myth in which Socialism is wholly comprised.... It colours with an intense life all of the details of the composition presented to consciousness. We thus obtain that intuition of Socialism which language cannot give us with perfect clearness-and we obtain it as a whole, perceived instantaneously. 
Sorel, supra note 30, at 145 . Elsewhere (187), Sorel describes the proletarian general strike as "awaken[ing] in the depths of the soul a sentiment of the sublime proportionate to the conditions of a gigantic struggle."

35. Derrida, "Force of Law," supra note 29, at 287.

36. As Dimock suggests, there is no resolution without residue. Dimock, supra note 1 , at 7 .

37. See Walter Benjamin, "Theological-Political Fragment," in Reflections, supra note 5, at 31 2-13.

38. Benjamin, "Critique of Violence," in Reflections, supra note 5, at 300 (my interpolation, my emphasis).

39. Proust, Swann's Way, supra note 19 , at 58 .

40. The historical materialist "has to brush history against the grain--even if he needs a barge pole to do it." Benjamin, "Paralipomena to 'On the Concept of History," in Selected Writings, supra note 12 , at 407. On "hacking" see supra note 5.

4I. Threepenny Novel was Brecht's attempt to translate the "epic theater" of Threepenny Opera into novel form. Of epic theater, Luban writes, "Epic theater does not aim at a celebratory or empathic rendition of events and characters. Rather it aims at a cooler, more distant presentation-what Brecht termed an alienation effect-designed to make its audience aware of alternative possibilities." Luban, supra note 12, at 383 . The audience was to observe and make decisions. In his own assessment of epic theater, Benjamin likened the ideal audience to readers of a novel. Epic theater's main task was to be didactic, not to develop action (drama) but to represent conditions, "the conditions of life." Benjamin, "What Is Epic Theater," in Illuminations, supra note 12, at 147, 150 . In Threepenny Novel Benjamin saw the outcome of the translation as satire, in the sense of "strip[ping] the conditions in which we live, removing the drapings of legal concepts." Benjamin, "Brecht's Threepenny Novel," in Reflections, supra note 5, at 201.

42. Addressing his associate, Grooch, MacHeath speaks as follows (Brecht, Threepenny Novel, supra note 11 , at $246-47$ ):

Grooch ... you are an old burglar. Your profession is burglary. I wouldn't think of suggesting that your profession, in itself, is out of date. That would be going too far. Only in its form, Grooch, does it lag behind the times. You are an artisan, a hack, and that's all there is to it. That class is on the wane-you can't deny that. What is a pick-lock compared to a debenture share? What is the burgling of a bank compared to the founding of a bank? What, my dear Grooch, is the murder of a man compared to the employment of a man? Take an example. A few years ago we stole a whole street of wooden blocks; we dug the blocks out, loaded them on to a cart and drove away with them. We thought we had done something wonderful. In reality we had only made ourselves unnecessary work and run an unnecessary risk. Shortly afterwards I heard that one only has to be a town councilor in order to be able to arrange the distribution of contracts oneself. Then one gets the contract for such and such a street and also several years' guaranteed profits without running any risks at all ... Nowadays a man must work within the law; it's just as much fun! . . Brute force is out of date. Why send out murderers when one can employ bailiffs? We must build up, not pull down; that is, we must build up for profit.

43. Benjamin, "Brecht's Threepenny Novel," in Reflections, supra note 5 , at 201.

44. Id.

45. Brecht, Threepenny Novel, supra note II, at 9. Fewkoombey, says Benjamin, is "transparent and faceless,' like the millions who fill barracks and basement apartments. Hard against the frame, he is a lifesize figure pointing into the picture." Benjamin, "Brecht's Threepenny Novel," in Reflections, supra note 5 , at 196.

46. That Fewkoombey dreams the Day of Judgment underlines justice's atemporality. Benjamin has a lot to say about dreams, although this is better addressed through his commentary on Proust than on Brecht. "Actualization" is Benjamin's way of describing how Proust tries to lay himself (and us) 
open not to the reflective intelligence of purposeful remembering, the activity from which we derive our historicist philosophy of history and time, but to the stir to the mind of involuntary recollection. Actualization is alien to our modern reflective intellect, so we suppress it. So completely does actualization contrast with reflection that, Benjamin says, it seems closer to what we think of as forgetting than memory:

[1]s not this work of spontaneous recollection, in which remembrance is the woof and forgetting the $\operatorname{war}[\mathrm{p}]$, a counterpart to Penelope's work rather than its likeness? For here the day unravels what the night [h] as woven. When we awake each morning, we hold in our hands, usually weakly, and loosely, but a few fringes of the tapestry of lived life, as loomed for us by forgetting. However, with our purposeful activity and, even more, our purposive remembering each day unravels the web and the ornaments of forgetting. That is why Proust finally turned his days into nights, devoting all his hours to undisturbed work in his darkened room with artificial illumination, so that none of those intricate arabesques might escape him.

The analogy here is to Penelope, wife of Odysseus, King of Ithaca, who tricks her suitors during Odysseus's long absence by claiming she cannot choose one of them until she has finished weaving a shroud for Odysseus's father. Each day she weaves, each night she undoes what she has woven. Here Benjamin (in counterpoint, day turned into night) is arguing that the purposive remembering of daytime undoes the wisps of involuntary recollection- "the few fringes of the tapestry of lived life"that come to us in the night. He calls involuntary recollection close to what we think of as forgetting, because we allocate "reality" to what purposive reflective remembrance produces. Under purposive remembering's relentless submersive assault we surrender involuntary recollection to the realm of dream and fantasy, so easily "forgotten" in the light of day. This is, Benjamin argues, precisely what historicism does: it substitutes reflection for memory and induces us to forget. "There is no telling what encounters would be in store for us if we were less inclined to give in to sleep. Proust did not give in to sleep." See Benjamin, "The Image of Proust," in Illuminations, supra note 12, at 202-03.

47. Brecht, Threepenny Novel, supra note II, at 384 . The uprising is also dreamed by Brown, the chief of police who is allied with MacHeath (id. at 346-47). In Brown's dream the masses literally rise up out of the river Thames.

48. Id. at 384. See Benjamin, "Theses," supra note 12, at Thesis 3: "only a redeemed mankind receives the fullness of its past - which is to say, only for a redeemed mankind has its past become citable in all its moments. Each moment it has lived becomes a citation à l'ordre du jour - and that day is Judgment Day."

49. Brecht, Threepenny Novel, supra note 11, at 384 .

50. Benjamin does not argue that the consciousness of dreams is somehow superior to that of "reality." The question rather is what knowledge one possesses upon awakening, what knowledge one brings to bear on the reality that presents itself to one's senses. Noting Marx's observation that " $[t]$ he reform of consciousness consists solely in ... the awakening of the world from its dream about itself," Benjamin comments, "Here the concern is to find the constellation of awakening." Arcades Project, supra note 13, at $45^{6}$, epigraph, $458 \mathrm{~N}_{1,9}$. See also ${ }_{46} \mathrm{~N}_{4} \mathrm{~N}_{3}, \mathrm{~N}_{4,4}$.

51. Brecht, Threepenny Novel, supra note II, at 396.

52. Id. at 380 .

53. Id. at 396 .

54. Fewkoombey's dream has momentarily echoed Athena in Eumenides: "I will establish . . . a tribunal, a tribunal for all time." See Luban, supra note 12, at 301 . Aeschylus means this, says Luban, "to stand for the beginning of the system of justice." In the instant of its dream-creation in Threepenny Novel, Brecht brings about its awakening-end. For an arresting literary parallel and its historical exploration, see Barker, Culture of Violence, $167-90$. 
55. Conrad, supra note 11 , at $67,103,122$.

56. Id. at 158 .

57. Id. at $65-66$.

58. Id. at 65. The conjunction is ominous. The Director "resembled a pilot, which to a seaman is trustworthiness personified. It was difficult to realize his work was not out there in the luminous estuary, but behind him, within the brooding gloom."

59. Id. at 69. Compare MacHeath's speech to Grooch, supra note 42.

6o. Id. at 80, 82. Marlow's metaphor for law invokes an incident he observes on his journey down the African coast (at 78 ):

Once, I remember, we came upon a man-of-war anchored off the coast. There wasn't even a shed there, and she was shelling the bush. It appears the French had one of their wars going on thereabouts. Her ensign dropped limp like a rag; the muzzles of the long six-inch guns stuck out all over the low hull; the greasy, slimy swell swung her up lazily and let her down, swaying her thin masts. In the empty immensity of earth, sky, and water, there she was, incomprehensible, firing into a continent. Pop, would go one of the six-inch guns; a small flame would dart and vanish, a little white smoke would disappear, a tiny projectile would give a feeble screech—and nothing happened. Nothing could happen. There was a touch of insanity in the proceeding, a sense of lugubrious drollery in the sight; and it was not dissipated by somebody on board assuring me earnestly there was a camp of natives - he called them enemies! — hidden out of sight somewhere.

African laborers, he says, two pages later, "could by no stretch of imagination be called enemies. They were called criminals, and the outraged law, like the bursting shells, had come to them, an insoluble mystery from the sea." Id. at 80.

61. Id. at 79,83 .

62. Id. at 92. "Each station should be like a beacon on the road towards better things, a centre for trade of course, but also for humanizing, improving, instructing." Id. at 101 .

63. Id. at $122,123,138$.

64. Id. at 153 .

65. Id. at 134 .

66. Id. at 147,149 :

He had summed up - he had judged. "The horror!" He was a remarkable man. After all, this was the expression of some sort of belief; it had candour, it had conviction, it had a vibrating note of revolt in its whisper, it had the appalling face of a glimpsed truth-the strange commingling of desire and hate. And it is not my own extremity I remember best-a vision of greyness without form filled with physical pain, and a careless contempt for the evanescence of all things - even of this pain itself. No! It is his extremity that 1 seem to have lived through. True, he had made that last stride, he had stepped over the edge, while I had been permitted to draw back my hesitating foot. And perhaps in this is the whole difference; perhaps all the wisdom, and all truth, and all sincerity, are just compressed into that inappreciable moment of time in which we step over the threshold of the invisible. Perhaps! I like to think my summing-up would not have been a word of careless contempt. Better his cry-much better. It was an affirmation, a moral victory paid for by innumerable defeats, by abominable terrors, by abominable satisfactions. But it was a victory! That is why I have remained loyal to Kurtz to the last, and even beyond, when a long time after I heard once more, not his own voice, but the echo of his magnificent eloquence thrown to me from a soul as translucently pure as a cliff of crystal.

67. Id. at ${ }^{4} 4$. Benjamin is famous for his observation, "[T]here is no document of civilization which is not at the same time a document of barbarism." "Theses," supra note 12 , at Thesis 7. Why not read 
Kurtz-apparent emissary of civilization turned barbarian —in this light? Why make him a voice of justice?

First, one must consider the valence of Benjamin's observation. An earlier formulation helps: "Barbarism lurks in the very concept of culture- as the concept of a fund of values which is considered independent, not indeed, of the production process in which these values originated, but of the one in which they survive." Arcades Project, supra note 13, 467-68 N 5a,7. In Heart of Darkness the values considered "independent of the production process in which they survive" (the harvesting of ivory) - are precisely those (pity, science, and progress) that the civilized, educated Kurtz had originally embraced and then, as barbarian, scorned. "All Europe contributed to the making of Kurtz" (Conrad, supra note 11, at 122-23). Europe's values were nowhere so deeply embedded as in the literal "document of civilization" that actually figures in Conrad's text, the report Kurtz wrote for the International Society for the Suppression of Savage Customs which "made him" so to speak "before his-let us say-nerves, went wrong." The report, says Marlow, "was a beautiful piece of writing." It held

"that we whites, from the point of development we had arrived at, 'must necessarily appear to them [savages] in the nature of supernatural beings - we approach them with the might of a deiry,' and so on, and so on. 'By the simple exercise of our will we can exert a power for good practically unbounded,' etc., etc.... It gave me the notion of an exotic Immensity ruled by an august Benevolence." But "a kind of note at the foot of the last page, scrawled evidently much later, in an unsteady hand, may be regarded as the exposition of a method. It was very simple, and at the end of that moving appeal to every altruistic sentiment it blazed at you, luminous and terrifying, like a flash of lightning in a serene sky: 'Exterminate all the brutes!'” (Id. at 123).

Second and relatedly, one must consider the duality of "barbarism" in Benjamin's writing. Note, for example, "Experience and Poverty" (1933), Selected Writings, supra note 12, at vol. L, pt. L, 732:

With the[e] tremendous development of technology, a completely new poverty has descended on mankind.... poverty of human experience in general. Hence, a new kind of barbarism. Barbarism? Yes, indeed. We say this in order to introduce a new, positive concept of barbarism. For what does poverty of experience do for the barbarian? It forces him to start from scratch. ... Among the great creative spirits, there have always been the inexorable ones who begin by clearing a tabula rasa.

One can, in short, read Kurtz through the relationship of civilization with barbarism. But only if one first acknowledges that neither Heart of Darkness nor Benjamin describe a polarity, that the barbarism lurking in the document of civilization is civilization's own, and that civilization's barbarism rarely has anything to do with those whom civilization names barbarians (on which see J. M. Coetzee, Waiting for the Barbarians (London: Martin Secker \& Warburg, 1980)); second, that both Heart of Darkness and Benjamin detect a distinct duality in barbarism; and third, that in that duality it is open to us to portray Kurtz as an exemplification of the "new, positive concept of barbarism," and indeed of the inexorable "great creative spirit" who, starting from scratch, begins by clearing a tabula rasa. It is on that tabula rasa, I argue, that Kurtz inscribes judgment, and is therefore a voice of justice.

68. Conrad, supra note 11 , at 197. Marlow is the betrayer, substituting love for horror:

It seemed to me that the house would collapse before 1 could escape, that the heavens would fall upon my head. But nothing happened. The heavens do not fall for such a trifle. Would they have fallen, I wonder, if I had rendered Kurtz that justice which was his due? Hadn't he said he wanted only justice? But I couldn't. I could not tell her. It would have been too dark-too dark altogether. 
69. And it is folded within itself (id. at 103):

You lost your way on that river as you would in a desert, and burted all day long against shoals, trying to find the channel, till you thought yourself bewitched and cut off for ever from everything you had known once-somewhere - far away - in another existence perhaps. There were moments when one's past came back to one, as it will sometimes when you have not a moment to spare for yourself; but it came in the shape of an unrest ful and noisy dream, remembered with wonder amongst the overwhelming realities of this strange world of plants, and water, and silence. And this stillness of life did not in the least resemble a peace. It was the stillness of an implacable force brooding over an inscrutable intention. It looked at you with a vengeful aspect. I got used to it afterwards; I did not see it any more; I had no time. I had to keep guessing at the channel; I had to discern, mostly by inspiration, the signs of hidden banks; I watched for sunken stones; I was learning to clap my teeth smartly before my heart flew out, when I shaved by a fluke some infernal sly old snag that would have ripped the life out of the tin-pot steamboat and drowned all the pilgrims; I had to keep a lookout for the signs of dead wood we could cut up in the night for next day's steaming. When you have to attend to things of that sort, to the mere incidents of the surface, the reality - the reality, I tell you-fades. The inner truth is hidden-luckily, luckily. But I felt it all the same; I felt often its mysterious stillness watching me.

70. Id. at 67,68 . How does Conrad ask us to understand Marlow's tale? Essentially, in my view, in the same way Benjamin asks us to understand history, which is to say, very differently from the understanding suggested by the temporality of historicism. First Benjamin ("Theses," supra note 12, at Thesis 17):

Historicism rightly culminates in universal history. Materialistic historiography differs from it as to method more clearly than from any other kind. Universal history has no theoretical armature. Its method is additive; it musters a mass of data to fill the homogeneous, empry time. Materialistic historiography, on the other hand, is based on a constructive principle. Thinking involves not only the flow of thoughts, but their arrest as well. Where thinking suddenly stops in a configuration pregnant with tensions, it gives that configuration a shock, by which it crystallizes into a monad. A historical materialist approaches a historical subject only where he encounters it as a monad. In this structure he recognizes the sign of a Messianic cessation of happening, or, put differently, a revolutionary chance in the fight for the oppressed past. He takes cognizance of it in order to blast a specific era out of the homogenous course of historyblasting a specific life out of the era or a specific work out of the lifework. As a result of this method the lifework is preserved in this work and at the same time canceled*; in the lifework, the era; and in the era, the entire course of history. The nourishing fruit of the historically understood contains time as a precious but tasteless seed.

*(Here Benjamin uses the verb aufheben in its threefold meaning - to preserve, to elevate, to cancelwhich for Hegelian dialectics provides the term aufhebung (in English sublation) meaning simultaneous preservation and alteration (uplifting) arising from the encounter of contradictory elements, here through the process of "blasting out.")

Now Conrad, supra note 1 , at 68 :

The yarns of seamen have a direct simplicity, the whole meaning of which lies within the shell of a cracked nut. But Marlow was not typical (if his propensity to spin yarns be excepted), and to him the meaning of an episode was not inside like a kernel but outside, enveloping the tale which brought it out only as a glow brings out a haze, in the likeness of one of these misty halos that sometimes are made visible by the spectral illumination of moonshine. 


\section{Tomilns - Revolutionary Justice in Brecht, Conrad, and Blake}

The key here is the term Benjamin uses, "monad," which he derives from Leibniz's metaphysics. The following summary explanation is reproduced in slightly adapted form from Douglas Burnham, "Gottfried Wilhelm Leibniz (1646-1716): Metaphysics," which can be found at http://www. iep.utm.edu/l/leib-met.htm\#top (last accessed March 8, 2009). "Monad" means that which is one, has no parts, and is therefore not divisible. A monad is thus the fundamental existing thing. "Monad" is not simply another term for "atom." Whereas atoms are simple, uniform, and homogeneous - the smallest unit of extension of which all larger (extended) things are composed - monads are nonextended and individually distinct. Monads may be combined, but each is complete in itself, a complete concept. That is, each monad contains within itself all the predicates of the subject of which it is the concept. Thus the monad both exhibits properties and also contains within itself (virtually or potentially) all the properties it will exhibit in the future, as well as the "trace" of all the properties exhibited in the past. Leibniz describes the monad as "pregnant" with the future and "laden" with the past. All these properties are "folded up" within the monad; they unfold when they have sufficient reason to do so.

Conrad's "yarns of seamen" are monads, containing within themselves their meaning as "direct simplicity." Marlow "takes cognizance" of the chance immanent in this structure to tell a yarn that "blasts out" the meaning within, makes it visible, unfolds all its properties. The meaning becomes its context. Similarly, Benjamin's historical materialist encounters historical subjects as monads, and brings out (unfolds) all the meaning that lies within. Once "blasted out," neither the yarns of seamen nor historical subjects require further "contextualization"-placement in "homogenous empty time" - for their meaning to be constructed. It is already apparent.

Incidentally it seems worth noting that in his essay "The Storyteller" (1936), Selected Writings, supra note 12, at vol. 3, 144, Benjamin identifies the seaman as one of two "archaic representatives" of storytelling.

7I. In a related proposition, Marianne Constable considers justice to be located in law's silences. See Marianne Constable, Just Silences: The Limits and Possibilities of Modern Law (Princeton: Princeton, University Press, 2005). An arresting image of Benjamin's ties the propositions together. "In the fields with which we are concerned, knowledge comes only in lightning flashes. The text is the long roll of thunder that follows." Arcades Project, supra note 13, at 456 N 1, I.

72. E. P. Thompson, Witness Against the Beast: William Blake and the Moral Law (New York, 1993), 193 (emphasis added).

73. That is to say, his "leap in the open air of history." "Theses," supra note 12 , at Thesis 14.

74. Id. at Thesis I, Thesis B. David Luban treats the first reference as an "ingenious jest" twitting Marx for concealing "theology" in his science in the form of "a necessitarian theory of historical change." Luban, supra note 12 , at 281 . But Benjamin's invocation of the messianic did have a theological foundation and this was what he made central to the Theses' intervention in historical materialism. Benjamin wrote of himself, "My thinking is related to theology as blotting pad is related to ink. It is saturated with it. Were one to go by the blotter, however, nothing of what is written would remain." Arcades Project, supra note 13 , at $47 \mathrm{I}$ N7a,8.

75. Thompson, supra note 72, at 174. Like the yarns of seamen, "London" is a monad. See also Luban, supra note 12 , at $201-02$ (citations omitted), on Arendt:

Arendt believed we can achieve a "transparent display of the inner truth of the event" beyond the "ever-recurrent narration" that "solves no problems and assuages no suffering." That happens when the story becomes a "formed narrative" - formed, that is by art, by "poetry' in the broadest sense." Art, not mysticism, discloses the event's meaning. Arendt gives as an example Faulkner's $A$ Fable, which revealed the meaning of World War I in such a way that it became possible to say: "Yes, this is how it was." 


\section{Law \& Literature Volume 21 , Number 2}

76. William Blake, "London," in Thompson, supra note 72, at $174-75$. For reproductions of the poem printed from the original etched plate of 1794 with minor variations in punctuation, see Songs of Innocence and Experience, copy B, C, F, in Morris Eaves et al., eds., The William Blake Archive, http:// www.blakearchive.org/blake (last accessed March 8, 2009). Blake made several changes between his notebook draft and the etched plate. Thompson argues that collectively they concentrate the effect of the poem, its "intensity of apocalyptic vision." Thompson, supro note 72, at 187 . Among these revisions, "charter' $d$ " in lines $1-2$ of the first verse replaced the much less loaded "dirty," signifying as the poem developed an intent on Blake's part to establish a direct relationship between legal order and oppression, rather than simply describe oppression's environment.

77. See, generally, Thompson, supra note 72 , at $174-94$ -

78. Id. at $190-9 \mathrm{I}, 194$.

79. Walter Benjamin, "Theologico-Political Fragment," in Reflections, supra note 5, at 312-13.

80. Silvana Caporaletti, "The Thematization of Time in E.M. Forster's 'The Eternal Moment' and Joyce's "The Dead'," 43 Twentieth Century Literature 406 (1997). For a subtle and refined disquisition that questions this science/spirit polarity, see Kunal M. Parker, "Custom and History: Common Law Thought and the Historical Imagination in Nineteenth Century America" (unpublished Ph.D. dissertation, Princeton University, 2007), notably chs. 2 and 4.

81 . See Bergson, supra note 16 , and accompanying text.

82. Id. at 407 .

83. "The masses in Baudelaire: They stretch before the flâneur as a veil: they are the newest drug for the solitary ... the newest asylum for the reprobate and the prescript . . . the newest and most inscrutable labyrinth." Arcades Project, supra note 13, at 446 M 16,3 .

84. Roger Berkowitz, The Gift of Science: Leibniz and the Modern Legal Tradition (Cambridge, MA: Harvard University Press, 2005), ix-xvi. We have seen that Wai Chee Dimock also describes justice in terms of residues, but in a different inflection - "residues unsubsumed and unresolved by any order of the commensurate, residues that introduce a lingering question, if nothing else, into any program of justice, whether corrective, distributive, compensatory or revolutionary." Dimock, supra note 1 , at 5 .

85. Thompson, supra note 72 , at 196.

86. Let us consider for a moment whether it makes sense to present science as a singularity.

In certain respects Benjamin and Blake thought alike. Both were antinomian revolutionaries. But while Newton disgusted Blake, Leibniz left a deep impress upon Benjamin. Some of the difference we may ascribe to the century that separated Blake and Benjamin, but not all.

Newton and Leibniz were contemporaries. As is well known, each-independently-conceived of calculus. But they conceived of it in different ways. Deleuze writes (supra note 15 , at $97 \rightarrow 8$ ):

By determining magnitudes according to the speed of movements or intensities that form them ("fluxions"), Newton invents a calculus adequate to the movement of a fluid matter and even to its effects upon an organ. But, while considering that these fluxions disappear in the growing magnitude of which they are a part, Newton leaves aside the problem of knowing where the different parts remain. To the contrary, Leibniz's calculus, based on the reciprocal determination of "differentials," is strictly inseparable from a Soul, insofar as the soul alone conserves and distinguishes the small components. Leibniz's calculus is adequate to psychic mechanics where Newton's is operative for physical mechanics. The difference between the two is as much metaphysical as mathematical.

And again (id. at 103):

What Leibniz calls for, against Newton . . . is the establishment of a true form that cannot be reduced to an apparent whole or to a phenomenal field, because it must retain the distinction of its details and its own individuality in the hierarchy in which it enters. 
W' have here, in other words, two different sciences - the science of extension and mechanisms, and the science of monads. For some comments on this difference see supra, note 15.

87. Ovid Metamorphoses 1. 150; Shakespeare, Titus Andronicus, ed. Russ McDonald (New York: Penguin, 2000), 75. On law and justice in Titus Andronicus, see Christopher Tomlins, "Law's Wilderness: The Discourse of English Colonizing, the Violence of Intrusion, and the Failures of American History," in John Smolenski \& Thomas J. Humphrey, eds., New World Orders: Violence, Sanction and Authority in the Colonial Americas (Philadelphia: University of Pennsylvania Press, 2005), 21-46.

88. Berkowit $\%$, supra note 84 , at $x, 159-60$. In Leibniz's universe, this would be correct (id. at 52,53 ). But Leibniz's universe is not the only universe.

89. Numbers 16:1-18:32. It is precisely the story of Korah that Benjamin has in mind in his depiction of divine violence in "Critique of Violence." See Illuminations, supra note 12, at 297.

90. On "balance," see Dimock, supra note $\mathrm{I}$, at $\mathbf{1}-\mathrm{J}$. I have argued at several points in this essay that restorative "redemption" should not be placed ahead of revolution in Benjamin's work. For (to repeat) "[t]he Messiah comes not only as redeemer, he comes as the subduer of Antichrist." "Theses," supra note 12 , at Thesis 6, 255. If one considers "Critique of Violence," indeed, revolutionary justice is first of all expiation. Redemption is its consequence. 